\title{
Factors Affecting the Bank Credit: An Empirical Study on the Jordanian Commercial Banks
}

\author{
Mwafag Rabab'ah ${ }^{1}$ \\ ${ }^{1}$ School of Management, Ajloun National University, Jordan \\ Correspondence: Mwafag Rabab'ah, School of Management, Ajloun National University, Jordan. Tel: \\ 962-777-179-527. E-mail: mwafagr@yahoo.com \\ Received: February 25, 2015 \\ Accepted: March 16, 2015 \\ Online Published: April 25, 2015 \\ doi:10.5539/ijef.v7n5p166 \\ URL: http://dx.doi.org/10.5539/ijef.v7n5p166
}

\begin{abstract}
This paper aimed to examine the determinants of commercial banks' lending in Jordan. The study sample consisted of ten Jordanian commercial banks during the period 2005-2013. The study used the ratio of credit facilities to total assets as a dependent variable, and eleven independent variables including the ratio of deposits, ratio of non-performing loans, capital ratio, liquidity ratio, asset size, lending rate, deposits rate, window rate, legal reserve ratio, inflation and economic growth rate.

The results showed that the ratio of non-performing loans, liquidity ratio and window rate have a negative and significant impact on the ratio of credit facilities, while found that the bank size and the economic growth have a positive and significant impact on the ratio of credit facilities granted by commercial banks in Jordan. The study recommended Jordanian commercial banks to avoid excess liquidity, and to pay more attention to reduce the ratio of non-performing loans.
\end{abstract}

Keywords: bank credit, commercial banks', credit facilities, total assets, ratio of deposits

\section{Introduction}

The relationship between the economic growth and the level of development of the financial system in the country is strong; several early researchers such as Gurley and Shaw (1967), Goldsmith (1969), McKinnon (1973), Shaw (1973) and contemporary researchers like Beck et al. (2001), Levine (2002) and Rehman and Cheema (2013) indicated that the evolution of the financial system promotes the economic growth through increasing savings, improving the efficiency of the distribution of the funds available for borrowing, and encouraging the capital accumulation.

Demirguc-Kunt and Levine (2008) indicated that the regulated financial structure contributes to the provision of information about the possible investment opportunities and the proper allocation of capital, facilitates the process of trading, foreign exchange and risk diversification, in addition to the mobilization of savings to be exploited for the purposes of productivity, and also facilitates the exchange of goods and services.

As it is known, the structure of the financial system consists of the financial markets and the financial institutions, which exercise a mediating role in the economy; through such institutions, savings are allocated and funding is provided for various sectors.

Banks are considered one of the largest and most important types of financial institutions, and the most efficient in practicing the role of financial intermediation; they are considered the lifeblood of economy (Banga, 2013). The financial system based on banks provides information regarding the investment opportunities and it directs resources to productivity channels resulting in facilitating the process of the economic growth (Beck et al., 2001) where banks play a vital role in the economic development through the assembled broken savings that are used to finance investments; banks also facilitate the internal and external trade and the movement of money and capital (Saini \& Sindhu, 2014). Furthermore, the previous research has indicated that the countries that possess an advanced banking system grew faster than those whose banking system was weak (Levine, 1997).

The bank credit is considered one of the important functions carried out by banks, where it contributes to the provision of the necessary funding for all the sectors in the country, including the sectors of the household, business and government. The credit granted to those sectors is considered important for exercising their tasks in business, operations and investments, which helps them to achieve a real growth in output, which will reflect 
positively on the economy as a whole. Many studies have pointed to the fact that increasing the credit granted by such banks helps boost the economic growth (Acharya et al., 2009).

As for the Jordanian economy, indicators refer that it is based on banks where the bank assets accounted for $184 \%$ of the GDP during the last four years (2010-2013); however, the bank deposits formed 118\%, and the credit facilities granted by the banks in Jordan represented about $80 \%$ of the GDP during the same period (the Central Bank of Jordan, the Monthly Statistical Bulletin, April 2014). Through the previous indicators, it is clear that the banking system in Jordan is deep and widely dependent on banks; also, it is clear that banks have a significant contribution in financing the Jordanian economy as the facilities granted by banks constitute $80 \%$ of the GDP, which is generally considered a high percentage.

Based on the above, this paper examines the bank credit provided by the Jordanian commercial banks during the period 2005-2013, tests the factors affecting it, and figures out the mechanisms and means that can help increase the banking financing of the Jordanian economy.

\section{Bank Credit in Jordan}

The bank credit provided by the banks operating in Jordan is one of the most important sources of funding for the Jordanian economy where the credit facilities accounted for $80.5 \%$ of the GDP during the period 2000 to 2013 and the percentage of the credit facilities for the output reached its highest levels during 2005-2007 where it was $86.8 \%$ in $2005,91.4 \%$ in 2006 , and $93.1 \%$ in 2007 . This marked increase in the proportion of facilities goes to the strong economic growth witnessed by the Jordanian economy in those years, which caused a rise in the credit facilities significantly. It is also noted that there is a slight decline in the proportion of credit to the GDP during 2009-2011 due to the implications of the global financial crisis on the Jordanian economy causing a slowdown in the economic growth rates, which reflected in slowing the growth rates of credit facilities during that period. Figure 1 shows the behavior of the proportion of credit facilities granted by the banks operating in Jordan to the GDP during the period 2000-2013.

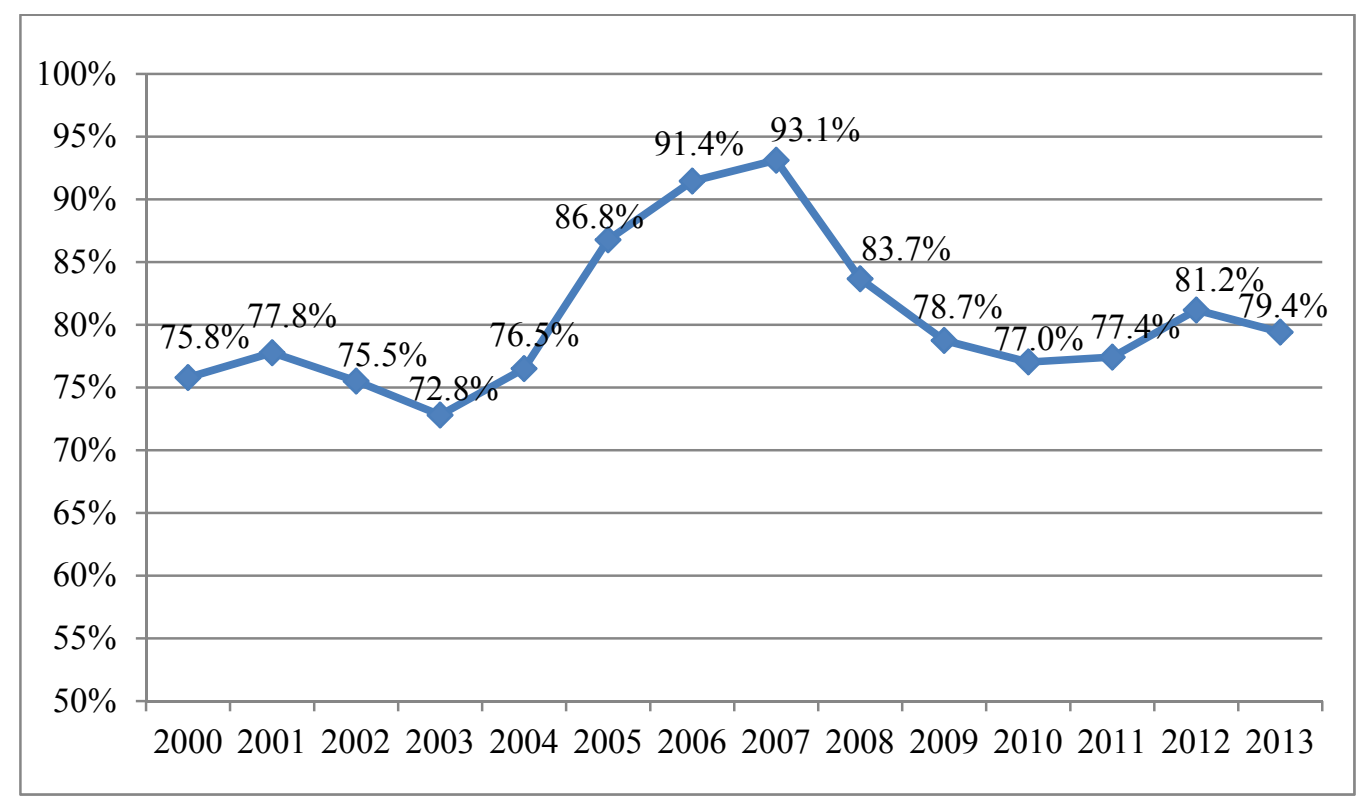

Figure 1. The proportion of the bank facilities to the GDP

The credit facilities granted by the banks in Jordan increased four times when they increased from 4.5 billion dinars in 2000 to reach 18.8 billion dinars in 2013 and the average of the annual growth rate in the facilities granted by the banks during the period 2000 to 2013 was about $11.1 \%$ annually. The facility has achieved the highest growth during the period 2004-2008, when the average growth rate was $20 \%$ annually and this strong growth in the credit facilities reflects large economic growth rates achieved by the Jordanian economy in that period. Regarding the lowest growth rates, they were achieved in 2009, when the growth rate of the facilities decreased to $2.1 \%$ in 2009 due to the implications of the global financial crisis on the economy of Jordan. Figure 2 shows the development of the credit facilities granted by the banks operating in Jordan, and their growth rates during the period 2000-2013. 


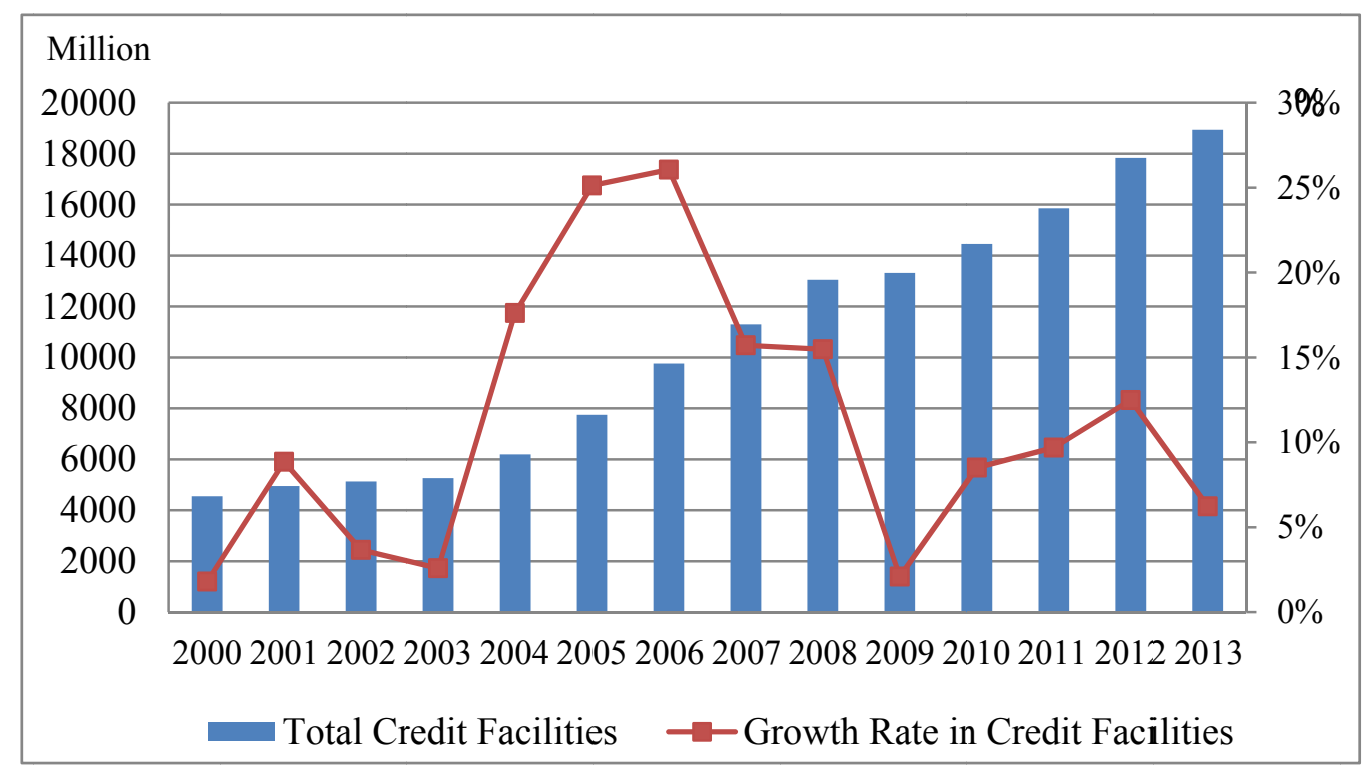

Figure 2. The development of the credit facilities granted by banks operating in Jordan

In terms of the distribution of the facilities granted by the banks in Jordan by the type of the facility, it can be noted that loans and advances constitute the largest proportion of these facilities representing $80.8 \%$ of the total facilities as an average for the period 2000-2013. The percentage of the total overdraft of the total facilities amounted to $15.8 \%$, while the percentage of the discounted bills and allocation was $3.4 \%$ of the total facilities. Figure 3 shows the distribution of the credit facilities granted by the banks operating in Jordan by type during the period 2000-2013.

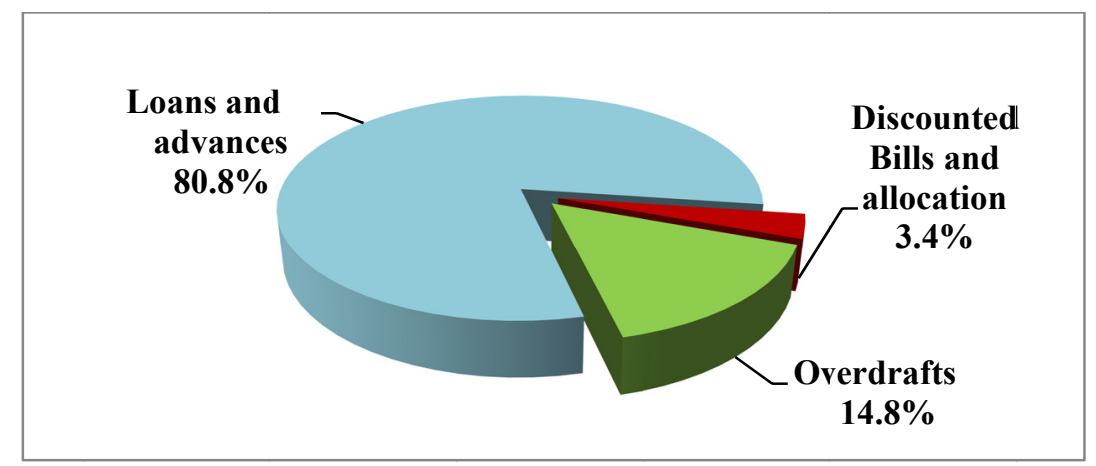

Figure 3. The distribution of the credit facilities by type during the period (2000-2013)

As for the distribution of the credit facilities granted by the banks operating in Jordan by the economic activity during the period 2000-2013, they are concentrated in three main sectors, where the sectors of the general trade, industry and construction were $54.8 \%$ of the credit facilities granted by the banks in Jordan; this also reflects the importance of these three sectors for the Jordanian economy as a whole in terms of their high contribution in the GDP reaching to more than $50 \%$. As for the credit facilities classified under "others", they represent mostly the facilities granted to individuals, which amounted to $26 \%$ of the facilities. It is noted that there is a decline in the sectors of mining, agriculture, financial services, transport, tourism, hotels and restaurants of the facilities granted by the banks operating in Jordan. Figure 4 shows the distribution of the credit facilities granted by the banks operating in Jordan by the economic sector during the period 2000-2013. 


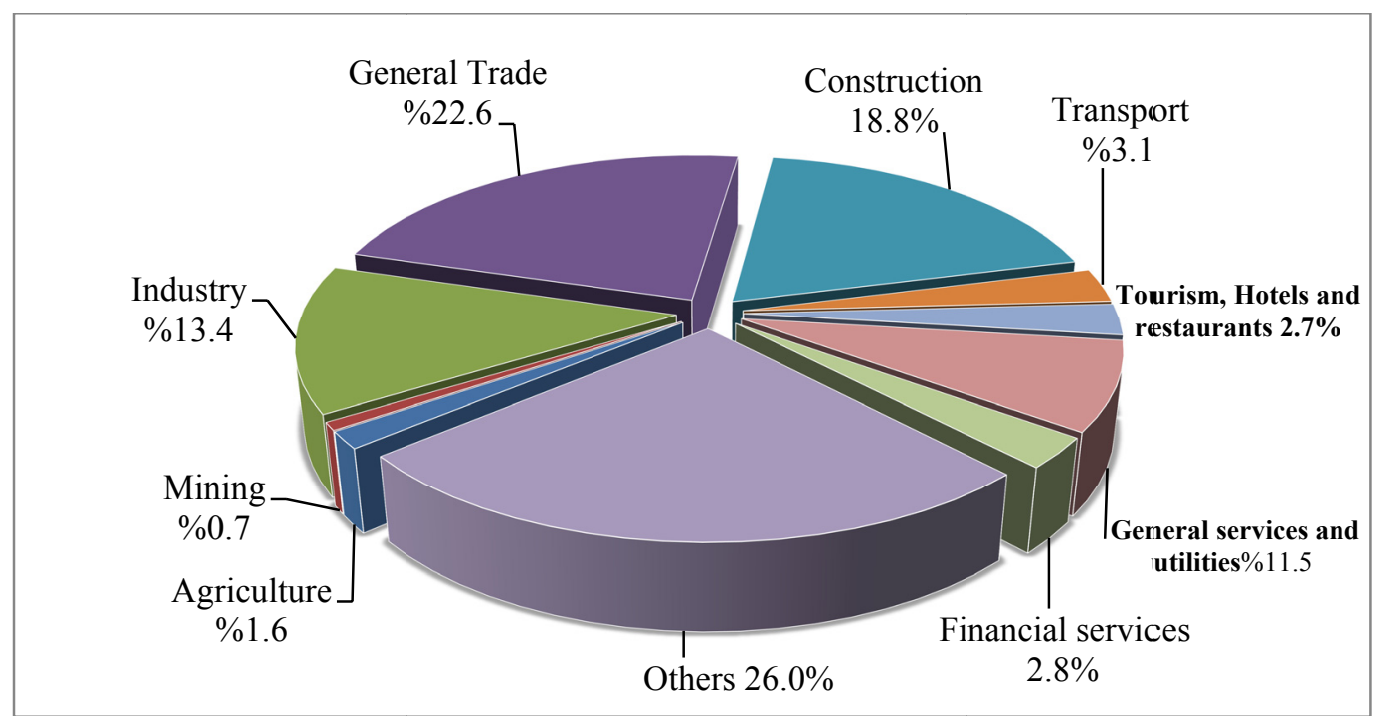

Figure 4. The distribution of the credit facilities by sector during the period (2000-2013)

Finally, with regard to the distribution of the credit facilities by the borrower during the period 2000-2013, it is noted that the private sector in Jordan accounted for $89.5 \%$ of the proportion of the total facilities. While the percentage of non-resident private sector was $4.9 \%$, and that of the central government and public institutions was $5.5 \%$. Figure 5 shows the distribution of credit facilities granted by the banks operating in Jordan by the borrower during the period 2000-2013.

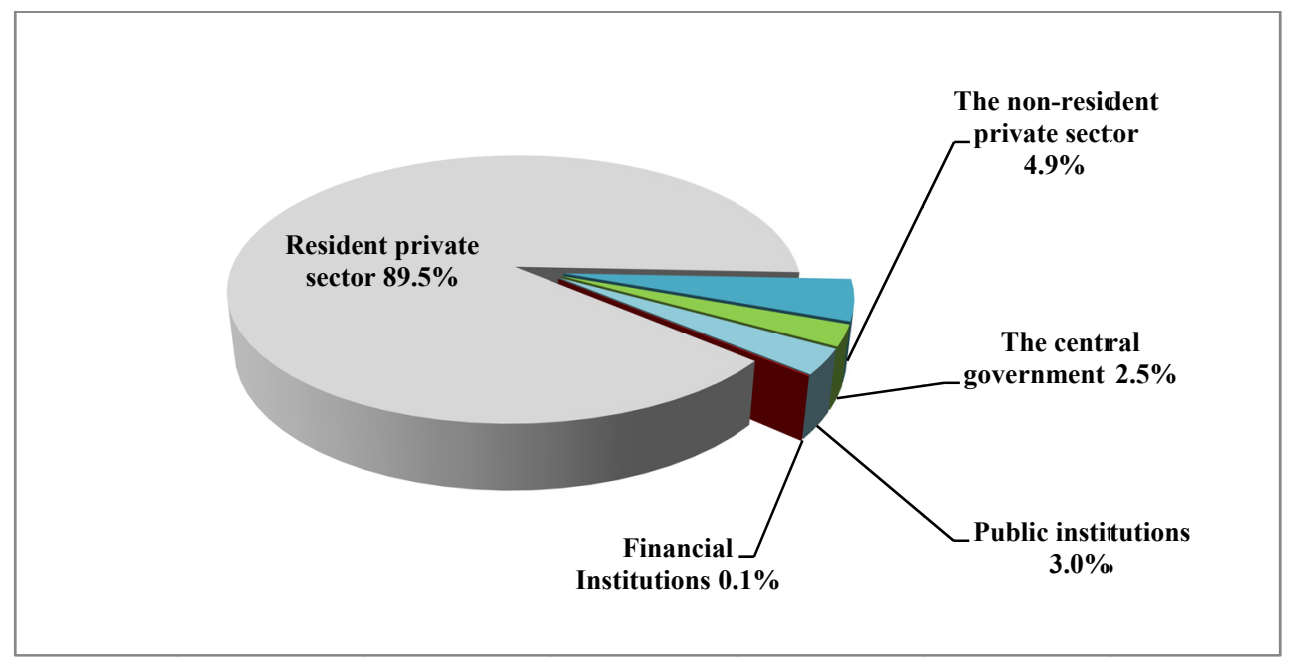

Figure 5. The disribution of the credit facilities by the borrower during the period (2000-2013)

\section{Previous Studies}

Imran and Nishatm (2013) examined the factors that explain bank credit provided to the companies in Pakistan during the period 1971-2008. The study focused on the supply side (the factors associated with the offer of money by the banks) through using the rate of growth in the bank credit provided to the private sector as a dependent variable, while the independent study variables included the rate of growth in the foreign liabilities, growth in the domestic deposits, the interest rate of the market, the money supply as a percentage of the GDP, the rate of the economic growth, the inflation and the exchange rate. The study results indicated that the foreign liabilities, local deposits, the economic growth, the exchange rate, and the monetary conditions have a significant impact on the size of the bank credit provided to the private sector in Pakistan, especially in the long tern. The results also show that the rate of inflation and the interest rate of the market do not affect the credit provided to the private sector. In the short term, the study found that the local deposits do not affect the credit provided to the private sector. 
Furthermore, the results indicated that the financial health and liquidity in banks play a vital role in determining the credit, and the good economic conditions induce banks to increase the volume of credit provided to the private sector.

Sharma and Gounder (2012) examined the change in the bank credit provided to the private sector in six economies in the South Pacific during the period 1982-2009. The study used the credit granted to the private sector as a dependent variable, while the independent variables included the average interest rate on the loans, the rate of inflation, the ratio of deposits to the GDP, the size of the banks' assets of output, a dummy variable reflecting the existence of a financial market, and the GDP. The results showed that the higher average interest rates on loans and the higher inflation rate may have negative effects on the rate of growth in credits, while the size of the deposits and assets had a positive impact on the growth of credit. The results also indicated that the strong economic growth leads to higher growth in credit.

Chernykh and Theodossiou (2011) conducted a study that was applied to a sample of Russian banks; it has found that the average of those banks granted only $50 \%$ of their total assets in the form of long-term loans to the business sector, with a significant difference in the ratio of one bank to another. The study pointed out that the bank's ability to increase the volume of long-term commercial loans depend on various factors, including the capital, volume and availability of long-term liabilities, while the ownership of the bank had no effect on the size of loans. The study also found that banks hesitate in issuing commercial loans for more than three years. Also, the study reported that the banks which have a low level of capital provide less long-term loans, and the banks that operate in areas with a high competitiveness hesitate in granting long-term loans. The study pointed to a series of obstacles faced by the banks in providing long-term loans to companies, including poor protection of the creditors' rights, and the lower creditworthiness of borrowers.

Olokoyo (2011) has discussed the determinants of bank lending for the commercial banks in Nigeria during the period 1980-2005, and their effectiveness in influencing the behavior of bank lending. The study sample included loans and advances granted by the Nigerian banks as a dependent variable, while the independent variables included the size of the deposit, the size of the investment portfolio, the interest rate on the loans, the reserve requirement ratio and the liquidity ratio. Through using the regression analysis, the results showed the statistical significance of the study model and the independent variables were as expected. The study results indicated that the deposits of the commercial banks have the biggest impact on the behavior of lending by the Nigerian banks. Also, the study suggested the need that the commercial banks attract more deposits because this will improve the performance of bank lending. Guo and Stepanyan (2011) has looked at the change in the bank credit across a broad range of emerging economies over the past decade. The study used the credit granted to the private sector as the dependent variable while the independent variables included the foreign liabilities of banks, the volume of domestic deposits, the rate of inflation, the real GDP, the interest rate on deposits, the exchange rate, non-performing debt, and the money supply. The results also indicated that the domestic and foreign financing contributes positively to the growth of credit provided by banks. The study also found that the strong economic growth leads to an increase in credit growth and inflation rates, and that the expansionary monetary policies locally and globally lead to an increase in the volume of credit and thus strengthening the banking sector.

Berrospide and Edge (2010) indicated that the impact of the bank's capital on the bank lending is a key factor that determine the relationship between the financial conditions and the real activities of the bank. The study used the method of shared regression analysis to test the bank lending by large banks, and found a slight impact of the capital on the size of the bank loans. While Bakker and Gulde (2010) found that external factors (unluckiness) were the main reason for the credit boom of the new members of the European Union.

Aisen and Franken (2010) indicated that the rate of growth in the bank credit before the financial crisis was higher than that after the financial crisis through the application on a sample of 80 countries. The study also found that the cyclical fluctuations in the monetary policy and the liquidity position of the banks have played a major role in the reduction of the bank credit provided after the financial crisis, which calls for the need that countries should follow economic and monetary structure accompanying the financial policies to face fluctuations. The results also indicate that countries have responded differently to the financial crisis because of the diversity in their structural characteristics, such as the financial depth and integration.

Takáts (2010) studied the bank lending behavior and found that during the financial crisis, the bank lending has fallen sharply across the border. By relying on the data of twenty-one emerging economies, the study found that during the financial crisis, the supply and demand factors contribute to the reduction of bank lending and that the supply shock was the main determinant of the slowdown of cross-border lending of the emerging markets during the crisis. 
Kamil and Rai (2010) showed that the sources of funding (external versus internal) become important during the crisis of the credit growth; the countries that rely more on the external financing suffer more than others. Barajas et al. (2010) showed that the internal factors in banks such as the capital and the quality of the loan help explain the differences in the credit growth across all the countries of the Middle East and North Africa. Grodzicki et al. (2010) examined the necessary conditions for the existence of a channel to carry the risks of the monetary policy in the Polish banking sector by testing whether the lending policies of each bank have an impact on the money supply of loans. The study relied on the survey data of the Polish bank lending with tuning the factors related to the demand side. Also, the study found that the individual bank lending policies of the banks constitute an important driver for the growth of credit; however, the financial constraints (capital and liquidity) were less important in determining the growth of credit. The study also demonstrated that the policies of bank lending were shifted to a large extent towards the perception of risks by banks. Furthermore, the study found that the efficiency of the transmission of the monetary policy may be weak in the small open economies such as Poland, compared with the large developed economies.

Ezirim (2005) confirmed that the decisions of the bank lending are subjected with a great deal of risks, which require a great deal of caution and dexterity in this aspect of the banking business. He pointed out that the success of all the lending activities depends to a large extent on the credit analysts to perform a good analysis of credit, in addition to the quality of the display and the structuring and preparation of reports.

Chodechai (2004) showed that the bank lending decisions involve a combination of factors, the most important of which are: the interest rates, the volume of lending, and the identification of collateral. He also showed that banks should be cautious when making the decisions of loan pricing; banks cannot impose very low interest rates on loans because the interest income will not be sufficient to cover the cost of deposits and general expenditures and the non-performing debt; furthermore, imposing high interest rates on loans may push borrowers to non-payment.

\section{Methodology}

Often, the studies dealing with bank lending examine the demand side or the supply side because studying the demand-side depends on examining the factors affecting the demand of individuals and companies for bank loans. However, the supply side focuses on the factors that affect the volume of loans granted by the banks, whether factors related to the banks themselves, such as their size, liquidity and the level of their deposit, the level of the borrowers' risks, the interest rates, in addition to the factors related to the total economic environment such as the economic growth, inflation rate and the exchange rates.

The current study addresses the determinants of bank lending in Jordan from the supply side in the sense of revealing the factors that push banks to lend more or less.

\subsection{The Study Sample and Population}

The number of banks operating in Jordan is 26, which are divided into 16 Jordanian banks and 10 (foreign) banks. The Jordanian banks consist of three Islamic banks and thirteen commercial banks (the Association of Banks in Jordan, the thirty four annual report 2012).

The study population consists of all the Jordanian commercial banks listed in the Amman stock market amounting to 13 . However, the study sample consists of ten Jordanian commercial banks which were randomly selected from the study population, which makes up about $77 \%$ of the study population.

\subsection{Study Data}

The study data includes annual data covering the period of time (2005-2013). The data of the study was obtained from the annual reports of the banks involved in the study sample, in addition to the statistical bulletin issued by the Central Bank of Jordan, and the reports issued by the Association of Banks in Jordan.

\subsection{The Study Model}

Based on the previous studies on the determinants of the bank lending especially Imran and Nishatm (2013), Sharma and Gounder (2012), Olokoyo (2011) and Guo and Stepanyan (2011), a group of factors and variables were extracted to develop a standard model record through which we can test the factors affecting the bank credit provided from the commercial banks in Jordan. The independent variables that have been adopted in this study included three main groups which are the internal variables related to the banks, the variables related to the monetary policy and the macroeconomic variables. The study model can be formulated as follows:

$$
\begin{gathered}
\frac{B C}{T A_{i, t}}=\alpha_{0}+\alpha_{1} \frac{D E P}{T A}+\alpha_{i, t} N P L s_{i, t}+\alpha_{3} C A P_{i, t}+\alpha_{4} L I Q_{i, t}+\alpha_{5} S I Z E_{i, t}+\alpha_{6} L R_{t}+\alpha_{7} D R_{t}+\alpha_{8} W R_{t} \\
+\alpha_{9} R R_{t}+\alpha_{10} I N F_{t}+\alpha_{11} G R T H_{t}+\varepsilon_{t}
\end{gathered}
$$


where $\mathrm{BC} / \mathrm{TA}_{\mathrm{i}, \mathrm{t}}$ represents the proportion of the credit facilities to the total assets provided from the bank $\mathrm{i}$ in the period t. DEP/TA $\mathrm{T}_{\mathrm{i}, \mathrm{t}}$ represents the ratio of deposits to the total assets of the bank $\mathrm{i}$ in the period t. NPLs $\mathrm{s}_{\mathrm{i}, \mathrm{t}}$ is the ratio of the non-performing loans to the total loans of the bank $\mathrm{i}$ in the period t. $\mathrm{CAP}_{\mathrm{i}, \mathrm{t}}$ is the ratio of the capital to the total assets of the bank $\mathrm{i}$ in the period t. $\mathrm{LIQ}_{\mathrm{i}, \mathrm{t}}$ represents the liquidity ratio to the total assets of the bank $\mathrm{i}$ in the period t. SIZE $i, t$ is the natural logarithm of the size of the assets of the bank $i$ in the period $t . \mathrm{WR}_{t}$ is the interest rate on the funds deposited in the window of deposit for the Central Bank of Jordan in the period t. $L_{t}$ is the average interest rate on the loans in period t. $\mathrm{DR}_{\mathrm{t}}$ is the average interest rate on the deposits in period $t . \mathrm{RR}_{\mathrm{t}}$ is the legal reserve ratio imposed by the Central Bank of Jordan on the banks in period t. $\mathrm{INF}_{\mathrm{t}}$ is the inflation rate in Jordan during the period t. GRTH $\mathrm{t}_{\mathrm{t}}$ is the rate of growth in the GDP in the period t.

\subsection{Defining the Variables of the Study}

(1) the dependent variable:

The proportion of the credit facilities to the total assets (BC/TA): the size of the credit granted by banks will be measured according to (Rodríguez \& Carbó, 2000) by dividing the total credit facilities granted by the bank in a given year on the size of the bank's assets in that year.

(2) the independent variables:

i. The ratio of the deposits to the total assets (DEP/TA): the ratio of the deposits to the total assets is considered one of the important factors that affect the volume of the granted credit because the increase of deposits in the bank offers more money that can be lent; this was confirmed by Imran and Nishatm (2013) which found that the high deposits have a positive impact on the rate of growth in the credit provided to the private sector. Olokoyo (2011) indicated that the volume of deposits in banks has a significant impact on the volume of bank lending. This variable will be measured by dividing the total deposits of the bank in a given year by the total assets in that year. It is expected that the effect of this variable is positive on the proportion of the credit facilities granted by banks.

ii. The ratio of the non-performing loans to the total loans (NPLs): Guo and Stepanyan (2011) indicated that the rise in the proportion of the non-performing debt leads to a decline in the strength of the banking sector and the volume of the credit granted. The study will also calculate the proportion of the non-performing loans by dividing the non-performing credit facilities in a given year by the total credit facilities granted by the bank in that year. It is expected that the effect of this variable is negative for the proportion of the credit facilities granted by banks.

iii. The ratio of capital to the total assets (CAP): Many studies have pointed out that the change in the capital has a significant impact on the volume of credit granted by banks because banks, which have a high capital are more capable to withstand losses through being emerged in the capital without reducing the value of the assets. On the contrary, the banks pursuit to maintain a constant level for the ratio of the capital to the assets may cause them to manage their assets more effectively and efficiently, and thus reducing the losses resulting from the granting of credit; this may reduce the volume of credit granted by the Bank (Olokoyo, 2011). this variable will be calculated by dividing the capital in a given year on the total assets of the bank in the same year. It is expected that this variable has a positive effect on the size of the credit facilities granted by banks because the capital increase makes the bank able to withstand a greater level of losses from lending operations.

iv. The Liquidity ratio to the total assets (LIQ): The size of the liquid assets held by the bank is one of the factors affecting the size of bank lending because the high liquidity ratio reduces the proportion of loans granted. Olokoyo (2011) used this percentage to explain the bank lending in Nigeria but the results of the study showed no impact for the liquidity ratio on the bank lending. The liquidity ratio will be measured by the sum of the cash and balances of the central banks, the balances and deposits of the banks and the banking institutions and the financial assets of the trade and dividing the result by the total assets. It is expected to have a negative effect of this variable on the proportion of credit facilities.

v. Asset size (SIZE): Several studies which investigated the determinants of bank lending used the size of the bank as an independent variable because of the importance of its impact on the volume of credit granted. Chernykh and Theodossiou (2011) indicated that the large banks are usually more diversified and they have large funds and more accessibility to borrowers from large companies with a high credit card balances, in addition they possess adequate resources for the development of advanced systems to manage and assess the credit risks. This makes the largest banks able to give a greater level of credit facilities. the size of the bank will be measured through the natural logarithm of the size of the bank's assets in each year of the study period. It is expected that this variable has a positive effect on the dependent variable.

vi. The average interest rate on loans (LR): the interest rate on loans is considered the most important source of income for the bank, and the high interest rate is usually accompanied by the increase in the amount of the money 
offered for lending. Chodechai (2004) has pointed out that banks should be cautious when determining the interest rates on loans where the imposition of low interest rates will affect the returns achieved by the bank, which should be sufficient to cover the cost of deposits and general expenses and losses in the loan portfolio resulting from faltering some customers. Also, imposing high interest rates on loans might lead borrowers to deliberately avoid paying the loans. This study will be based on the average annual interest rate on the loans and advances granted by banks. The effect of the interest rate might be positively or negatively effective on the volume of bank lending because the increase in the interest rate may encourage banks to provide more loans, but at the same time could lead to reduced demand for loan borrowers because of their high interest rates.

vii. Average deposit rate (DR): deposits constitute one of the main sources of funds for banks; the interest rate paid by the bank on the deposits is one of the most important components of the funds entrusted to it. The high interest rates on deposits reflects the high cost of bank money which leads to increasing the interest rates on loans, which in turn reduces the demand for bank loans for their higher interests. Guo and Stepanyan (2011) found that the high interest rates on deposits reduce the rate of growth in credit. It is expected that this variable has a negative effect on the proportion of credit facilities.

viii. The interest rate on the funds deposited in the window of deposit in the central bank (WR): banks with high liquidity may employ a part of their funds through depositing them in the deposit window of the Central Bank of Jordan in exchange for getting a determined benefit that is called the deposit window interest rate. this variable was used to reflect the status and trends of the monetary policy as the expansionary monetary policies include reducing the interest rate of the deposit window which lead to reducing the interest rates on deposits and loans, and thus increases in the volume of bank lending, while the increase in the interest rate on the window is as a tight monetary policy leading to increased interest rates in the market and reduced size of loans (Guo \& Stepanyan, 2011). It is expected that this variable has a negative effect on the proportion of the credit facilities granted by banks.

viiii. The legal reserve ratio imposed by the Central Bank of Jordan on banks (RR): it represents the rate that banks should extract from their deposits in order to keep it at the Central Bank. Thus, the lower the legal reserve ratio, the more deposits volume that can be exploited by the Bank in lending, which increases the size of the credit facilities granted by banks. Several studies such as Olokoyo (2011) have indicated that the legal reserve ratio is considered an influential factor on the bank lending. It is expected that this variable has a negative effect on the proportion of credit facilities.

$\mathrm{x}$. The rate of inflation (INF): several studies such as Sharma and Gounder (2012) have indicated that the inflation rate had a negative impact on the rate of growth in credit because the growth in the volume of credit may be due to the high rates of inflation and not because of the increase in the real value of the facilities granted. On the other hand, the high inflation rates usually lead to an increase in the nominal interest rates on loans, which cause the decline in the demand for loans. This study will use the annual rate of change in the consumer price index as a measure of the level of inflation in Jordan. It is expected that this variable has a negative effect on the proportion of the credit facilities granted by banks.

ix. The economic growth rate (GRTH): The economic growth is one of the important factors that affect the bank lending because the high growth rates reflect high pace of economic activity in the country and its accompanying rise in demand for funding. Imran and Nishatm (2013) found that the economic growth has a positive effect on the bank credit. The economic growth will be measured by the rate of the annual change in the GDP at constant prices. It is expected that this variable has a positive effect on the proportion of credit facilities.

Table 1. Summary of variables used in the study

\begin{tabular}{|c|c|c|}
\hline Variable & Abbreviation & Measure \\
\hline Credit Facilities Ratio & $\mathrm{BC} / \mathrm{TA}$ & Credit Facilities / Total Assets \\
\hline Deposits Ratio & $\mathrm{DEP} / \mathrm{TA}$ & Total Deposits / Total Assets \\
\hline Capital Ratio & CAP & Capital / Total Assets \\
\hline Liquidity ratio & LIQ & $\begin{array}{l}\text { (Cash and balances at the central banks }+ \text { balances and deposits of the banks } \\
\text { and the banking institutions + marketable securities) / Total Assets }\end{array}$ \\
\hline average interest rate on loans & LR & the average annual interest rate on the loans and advances granted by banks \\
\hline Average deposit rate & DR & the average annual interest rate on deposits at the banks \\
\hline Window Rate & WR & The interest rate on the funds deposited in the deposit window in the central \\
\hline
\end{tabular}




\begin{tabular}{lll}
\hline & bank \\
Reserve Ratio & RR & The legal reserve ratio imposed by the Central Bank of Jordan on banks \\
Inflation Rate & INF & the annual change in the consumer price index. \\
economic growth & GRTH & the annual change in the GDP at constant prices \\
\hline
\end{tabular}

\section{Results}

\subsection{Descriptive Statistics}

Table 2 shows the descriptive Statistics related to the independent study variables; through this table, we can note that the average proportion of credit facilities to total assets (BC/TA) provided by the Jordanian commercial banks during the study period (2005-2013) was about $47.2 \%$ of the total assets. The ratio ranged from $29.1 \%$ to $62.9 \%$ and the standard deviation was $7.6 \%$. It is noted here that the proportion of the credit facilities is considered comparable between banks in general, as it enjoys a relative stability.

The average ratio of deposits to total assets (DEP/TA) was about $64.8 \%$, the ratio ranged between $41.9 \%$ and $87.6 \%$ and the standard deviation was $8.9 \%$. from above, it is noted that there is a relative stability in the deposits in the banks of Jordan as well as a convergence between the proportion of deposits in Jordan.

The average proportion of non-performing loans to total loans (NPLS) was about $9.88 \%$ during the study period, the ratio ranged from $0.26 \%$ to $31.9 \%$, and the standard deviation was $6.1 \%$. The average ratio of the non-performing loans is relatively high and is close to $10 \%$, which is an alarming proportion in the banking customs.

The average ratio of capital to total assets (CAP) was approximately $6.6 \%$, the ratio ranged from $7.7 \%$ to $2.4 \%$ and the standard deviation was $3.3 \%$. The capital ratio is generally low for the Jordanian banks as it varies from one bank to another and from one year to another.

The average Liquidity ratio (LIQ) was approximately $30.1 \%$, the ratio ranged from $14.6 \%$ to $47.5 \%$ and the standard deviation was $7.3 \%$. It is noted here that the proportion of liquidity at the Jordanian banks is high, unstable and varied from one bank to another and from one year to another.

The average size of the bank's assets (SIZE) was 9.29 logarithm (which is equivalent to 1.94 billion dinars), and the size of the banks ranged from 10.4 to 8.7 logarithm with a standard deviation of .46 logarithm .it is noted here that there is a large disparity between the sizes of the sample banks.

The average interest rate on loans (LR) was about $8.86 \%$ during the study period, and the interest rate ranged between $8.10 \%$ to $9.48 \%$ with a standard deviation of $36.6 \%$. The interest rates are relatively high compared with those of the surrounding countries, with slight variations in the interest rates during the study period.

The average interest rate on deposits (DR) was about $4.58 \%$ during the study period, and the interest rate ranged from $3.40 \%$ to $5.66 \%$ with a standard deviation of $85.4 \%$, reflecting the presence of a high volatility in the interest rates on deposits.

The interest rate on the funds deposited in the deposit window (WR) was about $3.64 \%$ during the study period, and the interest rate ranged between $2.0 \%$ to $5.25 \%$ with a standard deviation of $110 \%$, reflecting the presence of a high volatility in the interest rates of the deposit window and its large change during the study period.

The average legal reserve ratio (RR) was about $7.55 \%$ during the study period, and the reserve ratio ranged from $7.0 \%$ to $9.0 \%$ with a standard deviation of $68.9 \%$, reflecting the presence of a large fluctuation in the legal reserve ratio during the study period.

The average inflation rate (INF) during the study period was about $5.27 \%$, and the rate ranged from $-0.7 \%$ to $14.0 \%$ with a standard deviation of $3.6 \%$, reflecting the presence of a fluctuation in the rate of inflation and its difference from one year to another. The inflation rate is relatively high during the study period.

The average economic growth rate (GRTH) in Jordan during the study period was about $5.28 \%$, and the rate ranged from $2.3 \%$ to $8.2 \%$ with a standard deviation of $2.5 \%$. It is noted that there is instability in the economic growth rates in Jordan being different from year to another.

Finally, it is noted that the dependent variable is normally distributed where the importance of the Jarque-Bera test was greater than $5 \%$, which shows the normal distribution of the variable. The number of the views within the study sample was 90 , which reflect the data of 10 banks in nine years. 
Table 2. The descriptive statistics for the variables

\begin{tabular}{|c|c|c|c|c|c|c|c|c|c|c|c|c|}
\hline & $\underline{B C / T A}$ & $\underline{D E P} / T A$ & NPLS & $\boldsymbol{C A P}$ & $\underline{L I Q}$ & $\underline{S I Z E}$ & $\underline{L R}$ & $\underline{D R}$ & $W R$ & $\underline{R R}$ & INF & $\underline{G R T H}$ \\
\hline Mean & 0.4717 & 0.6484 & 0.0988 & 0.0661 & 0.3012 & 9.2877 & 8.8589 & 4.4578 & 3.6389 & 7.5556 & 0.0527 & 0.0528 \\
\hline Median & 0.4800 & 0.6519 & 0.0877 & 0.0572 & 0.3048 & 9.2338 & 8.9500 & 4.2300 & 4.0000 & 7.0000 & 0.0470 & 0.0548 \\
\hline Maximum & 0.6286 & 0.8764 & 0.3188 & 0.1570 & 0.4753 & 10.4098 & 9.4800 & 5.6600 & 5.2500 & 9.0000 & 0.1398 & 0.0817 \\
\hline Minimum & 0.2909 & 0.4187 & 0.0026 & 0.0237 & 0.1462 & 8.6970 & 8.1000 & 3.4000 & 2.0000 & 7.0000 & -0.0066 & 0.0231 \\
\hline Std. Dev. & 0.0760 & 0.0889 & 0.0612 & 0.0327 & 0.0734 & 0.4588 & 0.3659 & 0.8541 & 1.0997 & 0.6888 & 0.0362 & 0.0254 \\
\hline Skewness & -0.2834 & 0.0890 & 1.1452 & 0.6851 & 0.1379 & 1.1383 & -0.4895 & 0.0875 & -0.1932 & 0.8367 & 1.0588 & -0.0050 \\
\hline Kurtosis & 2.6938 & 2.6753 & 4.9780 & 2.8212 & 2.6363 & 3.6466 & 3.1256 & 1.4654 & 1.6673 & 2.4972 & 4.6184 & 1.1741 \\
\hline Jarque-Bera & 1.5567 & 0.5141 & 34.3436 & 7.1596 & 0.7814 & 21.0032 & 3.6530 & 8.9458 & 7.2206 & 11.4495 & 26.6393 & 12.5022 \\
\hline Probability & 0.4592 & 0.7733 & 0.0000 & 0.0279 & 0.6766 & 0.0000 & 0.1610 & 0.0114 & 0.0270 & 0.0033 & 0.0000 & 0.0019 \\
\hline Observations & 90 & 90 & 90 & 90 & 90 & 90 & 90 & 90 & 90 & 90 & 90 & 90 \\
\hline Cross-sections & 10 & 10 & 10 & 10 & 10 & 10 & 10 & 10 & 10 & 10 & 10 & 10 \\
\hline
\end{tabular}

\subsection{The Results of the Regression Analysis}

Table 3 shows the results of the regression analysis model for the study, which connects the proportion of the credit facilities granted by the banks of Jordan with a number of independent variables. As it is evident in the table, the coefficient ratio of the deposits to the total assets (DEP/TA) was positive but not statistically significant, which means that the proportion of deposits does not affect the ratio of credit facilities granted by the commercial banks in Jordan. This result differs from what is expected and what is fund by the previous studies in this field, such as Sharma and Gounder (2012) and Olokoyo (2011), which indicated that the deposits have a positive impact on the volume of the bank credit. The reason for this result might be resulted from the high liquidity of the Jordanian commercial banks; therefore, they can fund the loans by reducing the portion of the high liquidity.

The coefficient of the proportion of the non-performing loans to the total assets (NPLS) has been negative and has a statistical significance which means that the high proportion of the non-performing loans ratio reduces the credit facilities granted by the commercial banks in Jordan. This result is consistent with what is expected and with Guo and Stepanyan (2011), which reported that the rise in the proportion of the non-performing debt leads to a decline in the strength of the banking sector and the volume of the credit granted.

The results show that the coefficient ratio of the capital to the total assets (CAP) was negative but not statistically significant, which means that the proportion of the capital does not affect the ratio of the credit facilities granted by the commercial banks in Jordan. However, this result is different from what is expected, but it is consistent with several studies that have found that the effect of the capital was slight on the bank lending, such as Berrospide and Edge (2010).

The results indicate that the coefficient of the liquidity ratio (LIQ) was negative and has a statistical significance, which means that the high liquidity ratio reduces the proportion of the credit facilities granted by the commercial banks in Jordan. This result is consistent with what is expected, although some studies such as Olokoyo (2011) found that the proportion of liquidity does not affect bank lending. It is noted that the negative effect reflects the correlation between the liquidity ratio and the proportion of the credit facilities as they represent the uses of the bank funds.

The coefficient of the size of the bank (SIZE) is positive and has a statistical significance, which means that the greater the size of the bank the higher the percentage of the credit facilities granted. This result is consistent with what is expected and with Chernykh and Theodossiou (2011), which found that large banks are more diversified and able to give a greater level of credit facilities.

The results have referred to the lack of statistical significance for the coefficient of the average interest rate on loans (LR) and the coefficient of the average interest rate on the deposits (DR), which means that the interest rate on loans and the interest rate on deposits do not affect the ratio of credit facilities granted by the commercial banks in Jordan. This result may reflect the lack of elasticity of demand on the bank loans in Jordan so that the demand for loans is fixed regardless of the interest rate. This result also reflects that the proportion of facilities is not affected by the size of the deposits in the bank, so the change in the volume of deposits resulting from the change in interest rates does not affect the ratio of the credit facilities. This result differs from what is expected and what is found by Guo and Stepanyan (2011) that the high interest rates on deposits reduce the rate of growth in credits.

One of the most striking results is that related to the factor related to the interest rate of the deposit window, which was negative and has a statistical significance, which means that the high interest rate of the deposit window 
reduces the proportion of the credit facilities granted. This result is consistent with what is expected and what is indicated by Guo and Stepanyan (2011). this result can be explained by the fact that in the event of rising the interest rates on the deposit window, banks prefer to deposit funds in the deposit window of a high-security, rather than expand in granting credit facilities and take the risk of various credits.

The results showed that the coefficient of the legal reserve ratio (RR) was positive but not statistically significant, which means that the legal reserve ratio does not affect the ratio of credit facilities granted by the commercial banks in Jordan. This result differs from what is expected and with what was found by the previous studies such as Olokoyo (2011). The reason for this result might be that banks do not lend the full amount of deposits remaining after excluding the legal reserve ratio, but retain a large part of the deposits in the form of liquid assets, making the change in the reserve ratio not effective on the credit facilities granted.

Regarding the macroeconomic variables, the results show that the coefficient of the inflation rate (INF) was negative but not statistically significant, which means that the inflation rate does not affect the ratio of credit facilities granted by the commercial banks in Jordan. This result differs from what is expected and from what was found by several studies such as Sharma and Gounder (2012). This result can be explained by the lack of the effect of the interest rate of loans on the proportion of credit facilities extended by the Jordanian commercial banks, so the higher inflation rates may lead to an increase in the nominal interest rates on loans, but it does not affect the demand for loans.

The economic growth rate coefficient (GRTH) was positive and statistically significant, which means that the high rate of the economic growth increases the proportion of the credit facilities granted by the commercial banks in Jordan. This percentage is consistent with what is expected and with what was found by several studies such as Imran and Nishatm (2013), which reported that the economic growth has a positive impact on the bank credit.

Finally, the adjusted explanatory power was $73.5 \%$, which is considered high reflecting that the independent variables explain about three-quarters of the change in the independent variable. Durbin-Watson statistics show that the dependent variable does not suffer from the problem of the serial link. However, the F-statistic shows that the study model is appropriate.

Table 3. The results of the regression analysis $(*)$ of the model

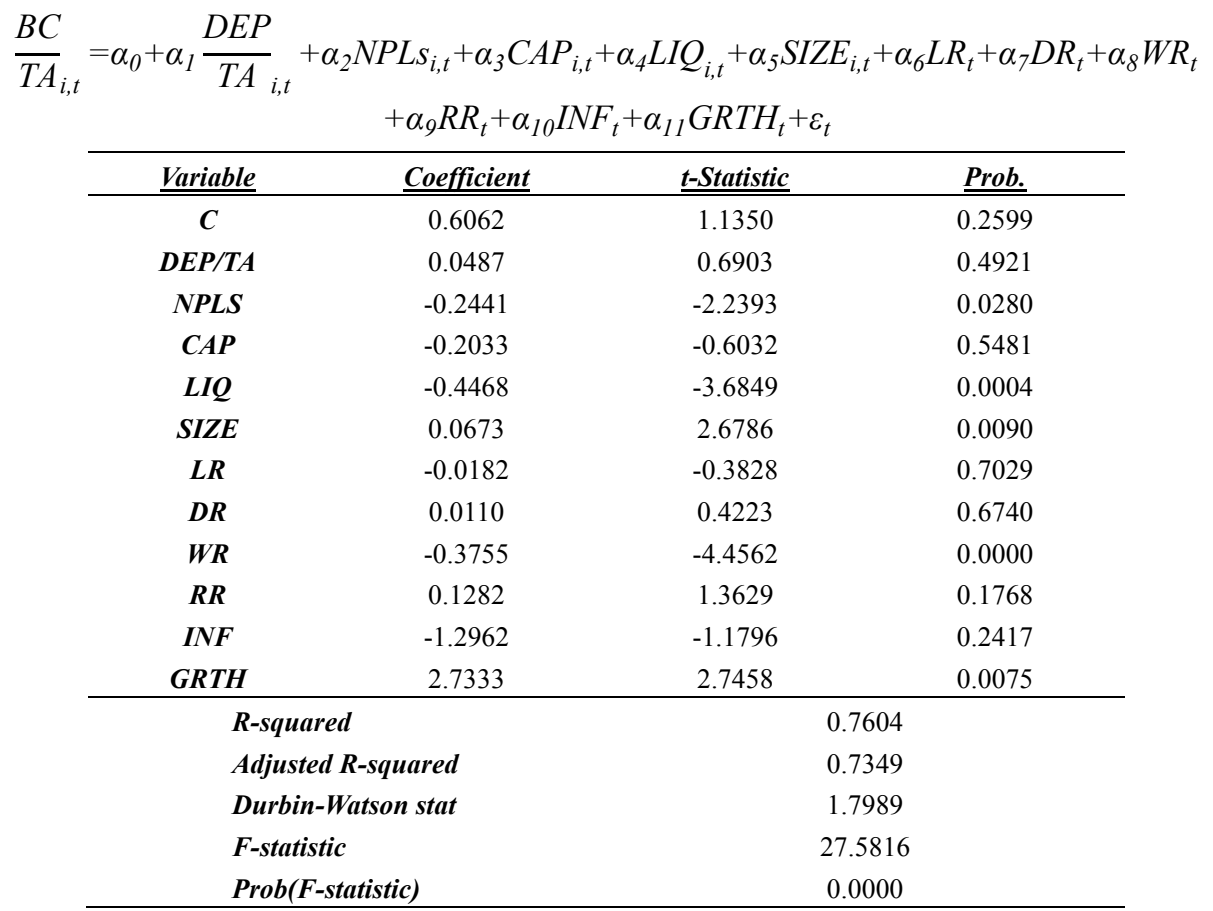

Note. $\left({ }^{*}\right)$ White standard errors \& covariance technique was used to correct heterogeneity in the variance.

\section{Conclusions and Recommendations}

This study examines the factors affecting the bank credit provided by the Jordanian commercial banks during the 
period 2005-2013. The study showed that the bank credit provided by the banks operating in Jordan is considered one of the most important sources of funding for the Jordanian economy, where the proportion of the credit facilities accounted for $80.5 \%$ of the GDP during the period 2000-2013.

The study also showed that the credit facilities granted by the banks in Jordan increased from 4.5 billion dinars in 2000 to 18.8 billion dinars in 2013 by an increase of more than a fourfold and an annual growth rate of 11.1 percent.

The average proportion of the credit facilities to the total assets of the commercial banks of Jordan during the study period was $47.2 \%$, while the proportion of the deposits accounted for $64.8 \%$ of the assets. The average ratio of the non-performing loans to the total loans was $9.88 \%$, while the average interest rate on loans was $8.86 \%$ and $4.58 \%$ on deposits. With regard to the interest rate of the deposit window, it has reached $3.64 \%$ and the average legal reserve ratio was $7.55 \%$. As for the macroeconomic variables, the study has shown that the average annual inflation rate was 5.27\%, while the total annual economic growth rate in Jordan was $5.28 \%$.

The results of the analysis of the study model revealed the absence of any statistically significant effect for each of the percentages of deposits, the percentage of capital, the interest rate on loans and deposits, the legal reserve ratio, and the rate of inflation on the proportion of the credit facilities granted by the commercial banks in Jordan. While the ratio of the non-performing loans, the ratio of liquidity and the interest rate of the deposit window have a negative and a statistical significance on the proportion of the credit facilities granted by the commercial banks in Jordan. The regression results showed that the size of the bank and the rate of the economic growth have a positive and a statistically significant impact on the proportion of the credit facilities granted by the commercial banks in Jordan.

Based on the above, it is important that the Jordanian commercial banks avoid excessively maintaining the liquidity and seek to employ its cash balances during the expansion of granting credit facilities. Furthermore, the Jordanian commercial banks should pay more attention to the ratio of the non-performing loans through following prudent credit policies based on a realistic assessment of the credit risks and avoiding customers with high risks except the presence of sufficient guarantees.

Because of the important influence of the interest rate of the deposit window on the size of the bank credit, it is necessary that the central bank maintain low levels of the interest rate of the deposit window so as not to constitute a profitable alternative to commercial banks, which prompts them to reduce their deposits in the window and increase the credit facilities granted.

Finally, we should emphasize the efforts of the Central Bank of Jordan in increasing the minimum requirements of the bank capital, which contributes to creating the largest banking entities with an ability of granting a larger volume of credit facilities.

\section{References}

Acharya, D., Amanulla, S., \& Joy, S. (2009). Financial Development and Economic Growth in Indian States: An Examination. International Research Journal of Finance and Economics, 24, 117-130.

Aisen, A., \& Michael, F. (2010). Bank Credit During the 2008 Financial Crisis: A Cross-Country Comparison. IMF Working Paper 10/47 (Washington: International Monetary Fund).

Bakker, B., \& Anne-Marie, G. (2010). The Credit Boom in the EU New Member States: Bad Luck or Bad Policies? IMF Working Paper 10/130. Washington: International Monetary Fund.

Banga, S. (2013). Socio-Economic Significance of Commercial Banks in India: With Special Emphasis on Public Sector Banks. International Journal of Advanced Research in Management and Social Sciences, 2(1), 1-22.

Barajas, A., Chami, R., Espinoza, R., \& Hesse, H. (2010). Recent Credit Stagnation in the MENA Region: What to Expect? What Can Be Done? IMF Working Paper 10/219. Washington: International Monetary Fund.

Beck, T., Demirguc-Kunt, A., Levine, R., \& Maksimovic, V. (2001). Financial Structure and Economic Development: Firm, Industry, and Country Evidence (pp. 189-241). The MIT Press, Cambridge: Massachusetts, Ch. 5.

Berrospide, J., \& Edge, R. (2010). The Effects of Bank Capital on Lending: What Do We Know, and What Does it Mean? Finance and Economics Discussion Series, Divisions of Research \& Statistics and Monetary Affairs, Federal Reserve Board, Washington, D.C, 2010-44.

Chernykh, L., \& Theodossiou, A. (2011). Determinants of Bank Long-term Lending Behavior: Evidence from 
Russia. Multinational Finance Journal, 15(3/4), 193-216.

Chodechai, S. (2004). Determinants of Bank Lending in Thailand: An Empirical Examination for the years 1992-1996. Unpublished Thesis.

Demirguc-Kunt, A., \& Levine, R. (2008). Finance, Financial Sector Policies and Long Run Growth. The International Bank for Reconstruction and Development. World Bank Economic Review, 10(2), 223-239. http://dx.doi.org/10.1093/wber/10.2.223

Ezirim, B. (2005). Finance Dynamics: Principles, Techniques and Applications. Port Harcourt: Markowitz Centre for Research and Development.

Goldsmith, R. (1969). Financial Structure and Development. New Haven, CT: Yale University Press.

Grodzicki, M., Hałaj, G., \& Zochowski, D. (2010). Commercial Bank Lending Policy and Loan Supply. Retrieved from http://www.grzegorzhalaj.pl/LoanSupplySurveys.pdf

Guo, K., \& Stepanyan, V. (2011). Determinants of Bank Credit in Emerging Market Economies. International Monetary Fund Working Paper, European Department, No. WP/11/51.

Gurley, J., \& Shaw, E. (1967). Financial Structure and Economic Development. Economic Development and Cultural Change, 15(3), 257-268. http://dx.doi.org/10.1086/450226

Imran, K., \& Nishatm, M. (2013). Determinants of Bank Credit in Pakistan: A Supply Side Approach. Economic Modeling, 35(C), 384-390. http://dx.doi.org/10.1016/j.econmod.2013.07.022

Kamil, H., \& Kulwant, R. (2010). The Global Credit Crunch and Foreign Banks'Lending to Emerging Markets: Why Did Latin America Fare Better? IMF Working Paper 10/102. Washington: International Monetary Fund.

Levine, R. (1997). Financial Development and Economic Growth: Views and Agenda. Journal of Economic Literature, 35(2), 688-726.

Levine, R. (2002). Bank-based or market-based Financial systems: Which is better? Journal of Financial Intermediation, 11, 398-428. http://dx.doi.org/10.1006/jfin.2002.0341

McKinnon, R. (1973). Money and Capital in Economic Development. The Brookings Institute, Washington.

Olokoyo, F. (2011). Determinants of Commercial Banks' Lending Behavior in Nigeria. International Journal of Financial Research, 2(2), 61-72. http://dx.doi.org/10.5430/ijfr.v2n2p61

Rehman, A., \& Cheema, A. (2013). Financial Development and Real Sector Growth in Pakistan. Interdisciplinary Journal of Contemporary Research in Business, 5(1), 618-636.

Rodríguez, F., \& Carbó, S. (2000). Microeconomic Determinants of Bank Lending: An Application to the Spanish Case. The 3rd Meeting of Applied Economics Conference, Valencia. June 2000.

Saini, P., \& Sindhu, J. (2014). Role of Commercial Bank in the Economic Development of India. International Journal of Engineering and Management Research, 4(1), 27-31.

Sharma, P., \& Gounder, N. (2012). Determinants of bank credit in small open economies: The case of six Pacific Island Countries. Discussion Paper Finance, Griffith Business School, Griffith University, No. 2012-13. http://dx.doi.org/10.2139/ssrn.2187772

Shaw, E. (1973). Financial Deepening in Economic Development. Oxford University Press.

Takáts, E. (2010). Was it credit supply? Cross-border bank lending to emerging market economies during the financial crisis. BIS Quarterly Review. Basel: Bank for International Settlements, June.

\section{Copyrights}

Copyright for this article is retained by the author(s), with first publication rights granted to the journal.

This is an open-access article distributed under the terms and conditions of the Creative Commons Attribution license (http://creativecommons.org/licenses/by/3.0/). 